\title{
Military expenditure in Greece: Security challenges and economic constraints
}

\section{Christos Kollias, Suzanna-Maria Paleologou, and Andreas Stergiou}

Christos Kollias is Professor of Economics at the Department of Economics, University of Thessaly, Greece. The corresponding author, he can be reached at kollias@uth.gr. Suzanna-Maria Paleologou is Associate Professor of Economics at the Department of Economics, Aristotle University of Thessaloniki, Greece. She can be reached at smp@econ.auth.gr. Andreas Stergious is Assistant Professor of European Politics at the Department of Economics, University of Thessaly, Greece. He can be reached at snandreas@econ.uth.gr.

\section{Abstract}

Against the backdrop of significant political, economic, and security-related changes that have taken place over the past two decades or so, this article examines the factors that affect military expenditure in Greece. Invariably ranked among the countries with the highest defense burden in the EU and NATO, it would appear that such budgetary outlays have mostly been driven by the ability of the economy to allocate scarce resources to national defense and less so by external security considerations.

$\mathrm{O}$ ne of the state dyads that have attracted considerable attention in the defense and peace economics literature, is Greece and Turkey. Both have invariably ranked as countries with a relatively high military burden among NATO and EU members. Based on SIPRI data, during 1960-2014 an annual average of 3.9 percent of GDP was allocated to defense by Greece, and 3.4 percent by Turkey, while the NATO average was 2.9 percent. In the post-bipolar period, 1990-2014, compared to the European Union's average military burden of 1.9 percent, Greece's was 2.9 and Turkey's 3.2 percent. Not surprisingly, both have featured as case studies, either as a single country or as dyad, in many published papers. One strand of this literature has set out to examine the extent to which the military outlays of one country affect those of the other. This theme has been examined either in the context of an arms race or in terms of a demand for military spending empirical set-up. Methodological problems and weaknesses in the accumulated body of literature have been thoroughly reviewed and hence, for reasons of brevity, we refrain from repeating a similar exercise here. In any case, our aim is substantially narrower since we concentrate on the postbipolar period (1990-2014), focusing mainly on defenserelated changes and developments in the case of Greece and empirically examining to what extend they have influenced Greek military expenditure. ${ }^{1}$

Historically, Greek-Turkish relations have been bumpy, with a number of issues dividing the two countries. Bilateral relations have been characterized by a repeating cycle of tension, negotiation, and tension. In the 1990s, both a sharp deterioration in this relationship and then a remarkable improvement was witnessed. The 1996 Imia crisis when a military flare-up was narrowly avoided only after stern intervention by the United States, the Öcalan affair in 1999, and the proposed deployment of Russian-made S-300 anti-aircraft missiles in Cyprus, are perhaps the most prominent cases of the deterioration in Greek-Turkish relations during this period. The 1999 earthquakes in Turkey and in Greece, and the mutual assistance offered by both, acted as the impetus of a rapid and probably unprecedented rapprochement that was further solidified by Greece's decision at the 1999 Helsinki EU Summit to consent to the granting of EU candidate status to Turkey. Since then, Greek-Turkish relations have, in comparative terms, thrived at the level of the economy and civil society, accompanied by bilateral agreements in what are considered as low-politics spheres. Trade has increased remarkably and significant economic cooperation emerged in the banking and tourism sectors. Nevertheless, there has been no fundamental progress toward a comprehensive Greek-Turkish settlement covering long-standing bilateral disputes that form the strategic core of their differences such as for instance the Cyprus problem, the delineation of territorial waters and of the continental shelf. Hence, Turkey still features prominently in the Greek security agenda. The question is whether this bears a statistically traceable impact on the Greek military budget or whether other factors exert a more significant influence. ${ }^{2}$

\section{Security shifts and economic fluctuations}

It is quite rare for two countries to see their systemic position in their regional relations and balance of power shift as rapidly as has been the case for Greece and Turkey over the past two decades or so. In the early 2000s, Greece entered the eurozone, 
Table 1: Average GDP growth rates and military expenditure as a percent share of GDP

$$
\text { Greece EU Eurozone }
$$

GDP growth rates $(\%)$

$\begin{array}{cccc}1990-99 & 2.1 & 2.2 & 2.2 \\ 2000-08 & 3.6 & 2.3 & 2.1 \\ 2009-14 & -4.8 & 0.1 & -0.2\end{array}$

Military expenditure (\% of GDP)

$\begin{array}{llll}1990-99 & 3.5 & 2.2 & 2.0 \\ 2000-08 & 2.9 & 1.8 & 1.7 \\ 2009-14 & 2.6 & 1.6 & 1.5\end{array}$

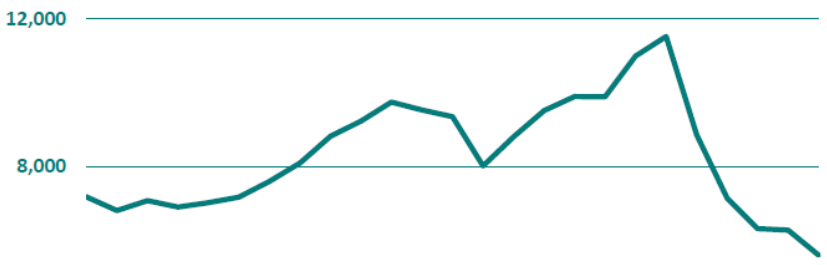

4,000

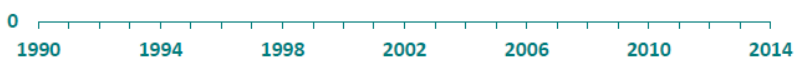

Figure 1: Greek real military expenditure (in constant 2011 USD). Source: Stockholm International Peace Research Institute (SIPRI).

an accession that was widely viewed as an important strategic achievement that strengthened the country's economic and political presence in the greater region. Roughly at the same time, the Turkish economy was experiencing a deep economic crisis, with important and long-lasting political ramifications. Less than ten years later a fundamental domestic political power shift was completed in Turkey with Erdogan's AKP party emerging as the strongest pillar in domestic politics, having swept away the old Kemalist partisan scene. Concurrently, a remarkable dynamic economic recovery unfolded, albeit now with clear signs of an impending slow-down. Turkey's ascent to one of the most vibrant G20 economies coincided with Greece's debt crisis that brought
Against the backdrop of significant political, economic, and security-related changes that have taken place over the past two decades or so, the article examines the factors that affect military expenditure in Greece. Invariably ranked among the countries with the highest defense burden in the EU and NATO, it would appear that such budgetary outlays have mostly been driven by the ability of the economy to allocate scarce resources to national defense and less so by external security considerations.

about an unprecedented recession with widespread social suffering and discontent as well as profound changes in the domestic political and partisan scene. As can be seen in Table 1 , the sovereign debt crisis that erupted in 2009, and the concomitant deep and prolonged recession, caused a traumatic reversal in the economy's performance. From the healthy growth rates of the 1990s and for most of the 2000s, the economy plummeted into an unprecedented free-fall from which it still has to recover with a steady pace. The debt crisis brought about stern austerity measures and imposed severe fiscal cutbacks with across-the-board decreases in public spending. As a share of GDP, military expenditure does not seem to have been substantially affected, however. From an average of 3.5 percent in the $1990 \mathrm{~s}$ and 2.9 percent in the pre-crisis $2000 \mathrm{~s}$, it marginally declined to 2.6 percent during the recession period (2009-2014), still being appreciably higher than the EU and eurozone averages (Table 1). However, the GDP share of military expenditure does not entirely reveal the size of the cutbacks that took place in the defense budget. In real terms, military spending in 2014 was more than 50 percent lower as compared to 2009 (Figure 1). Based on SIPRI data, the 2014 level of Greek military expenditure was, in real terms, the lowest throughout the entire post-bipolar period. Indeed, in 2014, it was only slightly higher than the level it was at back in 1973. (According to SIPRI data, Greek military spending in 1973 was around USD4.9 billion and in 2014 USD5.5 billion. It reached its highest level in 2009, the year the current economic crisis started unfolding, at around USD11.5 billion. $)^{3}$

Roughly at the same time that the Greek sovereign debt crisis erupted, an important change in the geopolitics of the region took place that had a direct bearing on Greece's regional position. Due to a series of diplomatic episodes and confrontations between 2008 and 2012, the Israeli-Turkish relationship entered into a period of tension and distrust, interrupting decades of cordiality and cooperation. The ensuing rift, and the gap it created in Israel's security strategy, was rapidly substituted for by Israel's quick forging of political, military, and energy relations with Greece and Cyprus. For 


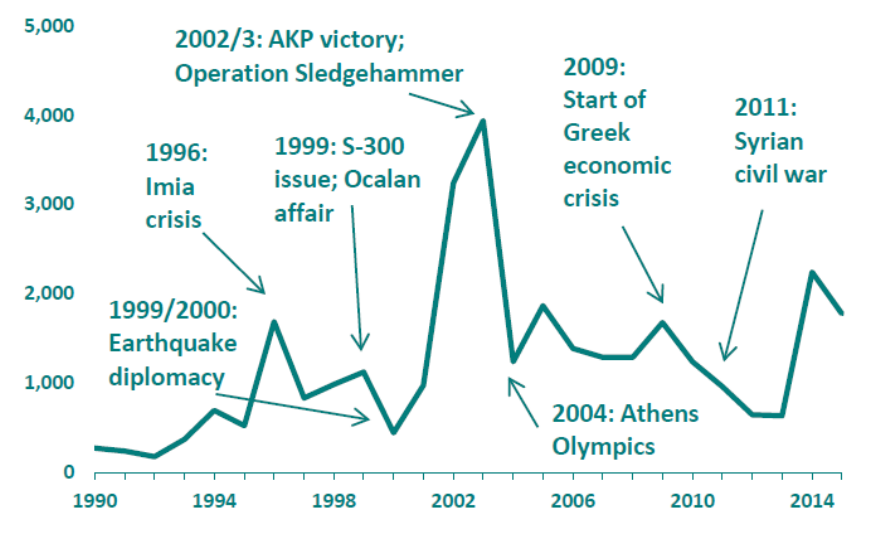

Figure 2: Number of Greek airspace violations by Turkey. Source: Greek Ministry of Defense, General Staff.

example, after Turkey suspended all joint military exercises with Israel, Greece offered to step in, replacing Turkey as a strategic defense partner for Israel. Energy reserves were the catalyst for improving bilateral relations between Israel and Greece, as the latter is seeking to upgrade its energy profile both in the short term, as a transit state for energy flows of natural gas coming from Israel and Cyprus to the European market, and, in the long term, as an energy producer. A similar pattern of events unfolded in the case of Egyptian-Turkish diplomatic relations following the 2013 coup that overthrew the Morsi government in Cairo. The deterioration in bilateral relations between Egypt and Turkey paved the way to improvements in Greece's diplomatic relations with Egypt, sealed by joint Greek-Egyptian military exercises. ${ }^{4}$

Although this epigrammatic summary of developments can hardly claim to be a comprehensive analysis of events, and of the changes the two countries have gone through over the last two decades or so, it does provide a backdrop highlighting the fluctuations that characterized their respective domestic scenes, affected their mutual relations, and their regional roles. Both aspire to become regional game changers and energy hubs in the eastern Mediterranean, a region characterized by a remarkable, ongoing reconfiguration of the balance of power and competition for hegemony. ${ }^{5}$

As noted, no major adverse episode has marred Greek-Turkish bilateral relations since the late 1990s. If anything, they seem to be going through a prolonged period of calm and cordiality. Nevertheless, no real headway has been made in the strategic core of the issues that divide the two countries. It should, however, be mentioned that, in recent months, negotiations for a resolution to the Cyprus problem have resumed, creating expectations of an impending settlement to this long-standing problem that has been a major thorn in Greek-Turkish relations. Yet this optimism may not convert into real and concrete progress given that thorny issues on property, territorial adjustments, demographic composition, security arrangements, and power-sharing still seem to be irreconcilable. Against this backdrop of economic and geopolitical changes, we now turn to examine empirically whether and, if so, to what extent Greek military expenditure is influenced by Turkish military expenditure in the postbipolar period.

Is it the economy?

Military expenditure essentially reflects the cost of producing military power. It represents a country's outlays to purchase the inputs needed for the production of military capabilities and strength. Given the primarily strategic nature of military expenditure, its evolution and fluctuation over time are hypothesized to reflect changes in the international system and the global or regional security environment. Dyads, such as Greece and Turkey, engaged in long-term disputes and conflicts, tend to get locked in persistently high levels of military spending. In the relevant defense economics literature, several factors are hypothesized as explanatory determinants of military expenditure. Standard estimating models for the demand for military spending typically assume that, among other things, such expenditures are determined by economic constraints, external threat(s), and spill-ins from allies. In line with this literature we assume that an individual country, in our case Greece, faces a constant elasticity demand function for military expenditures given in equation (1):

(1) $M_{t}=A p_{t}{ }^{\beta}$,

where $M_{t}$ is military expenditure, $p_{t}$ is the GDP deflator since there are no indices of the price of military activity for Greece, $\beta$ is the elasticity of demand, and $A$ includes various demand shifters. The demand shifters in our model include both domestic and external determinants. The external threatcapturing variables include Turkish military expenditure (TRmilex) and Greek airspace violations by the Turkish air force (Figure 2). The airspace violations variable has been used in a number of studies as an index of military tension. Such violations can be viewed as a signaling game between two countries over contested territory, in this case along the length of Greek airspace, communicating objections or claims that constitute a process of coercive diplomacy but in practice can be influenced by a cohort of factors ranging from prevailing weather conditions to domestic and external causes. ${ }^{6}$

As seen in Figure 2, the general trend of the time series of Greek airspace violations is an upward one. An interesting and 
Table 2: OLS estimates of demand equation, 1990-2014

Dependent variable: Greek military expenditure (constant 2011 USD)

\begin{tabular}{lcc} 
& Coefficient & p-value \\
lnTRmilex(t-1) & -0.519 & 0.109 \\
lnGDP(t) & $\mathbf{0 . 6 5 9}$ & $\mathbf{0 . 0 1 4}$ \\
lnGDPdeflator(1) & $-\mathbf{0 . 4 8 7}$ & $\mathbf{0 . 0 4 8}$ \\
lnGRcivilexp(t-1) & 0.623 & 0.070 \\
lnGRpop(t-1) & 0.326 & 0.629 \\
lnUSmilex(t-1) & $-\mathbf{0 . 7 5 5}$ & $\mathbf{0 . 0 0 0}$ \\
Violations(t-1) & -0.021 & 0.517 \\
R-squared & 0.84 & \\
S.E. & 0.078 & \\
DW & 1.201 & \\
Log likelihood & 31.095 & \\
Serial correlation & $\chi 2(1)=0.144$ \\
Functional form & $\chi 2(1)=0.284$ \\
Normality & $\chi 2(1)=0.814$ \\
Heteroskedasticity & $\chi 2(1)=0.402$ & \\
\hline &
\end{tabular}

Notes: Serial correlation test: Lagrange multiplier test of residual serial correlation; functional form test: Ramsey's RESET test using the square of the fitted values; normality test: based on a test of skewness and kurtosis of residuals; heteroskedasticity test: based on the regression of squared residuals on squared fitted values. Coefficients in bold type-font are highlighted at the conventional $5 \%$ level of statistical significance.

perhaps to some extent illuminating exercise for our purposes here is to try to identify events that might have affected the number of violations in specific years. A full econometric examination of the determinants of the number of violations is well beyond our scope here, so we simply restrict ourselves to a visually-based approach. We already referred to examples of important events that characterized Greek-Turkish bilateral relations in the 1990s, causing oscillation from a major military crisis (Imia, 1996) to a rapid rapprochement induced by the 1999 earthquakes. Both seem to have left an imprint on the time series in question (Figure 2). But this is merely a visual observation and by no means a robust assertion supported by hard evidence. ${ }^{7}$

A similar rise-and-fall pattern is seen from 2000 to 2004. Internal developments in Turkey might explain the sharp increase in airspace violations observed in 2002 and 2003. Allegedly, the possibility of electoral victory of Erdogan's AKP party in 2002, and his becoming Prime Minister of Turkey in 2003, set in motion a secularist military plan, codenamed Operation Sledgehammer, aimed at eventually overthrowing AKP in a coup. It has been claimed that the plan involved, among other things, staging a major military crisis with Greece via dogfights between the fighter planes of the two countries and the shooting down of a Turkish pilot. Hence, the sharp rise in the number of violations in 2002 and 2003 and the equally sharp decline once the alleged plot was thwarted. The decline coincides with the 2004 Olympic Games held in Athens. Airspace violations are a risk-generating mechanism since they often involve dogfights between armed jets and in the past have claimed pilots' lives. An accidental incident during a mega-sports event of global interest would have proved diplomatically embarrassing. ${ }^{8}$

As a final illustration, the Greek economic crisis that started in 2009 appears to have affected the number of violations up to 2013, as again can be seen in Figure 2. Similarly, the onset of the Syrian civil war in 2011 and the subsequent major security challenges this caused for Turkey on its southeastern boarder can be also cited as a possible factor explaining the downward trend exhibited during these years. ${ }^{9}$

We now return to equation (1). To capture alliance spill-ins we included U.S. military expenditure. In the geopolitics of the region in general, and Greek-Turkish relations in particular, the United States acts as a strategic supervisor and regulator given its hegemonic role in the NATO alliance as well as in global politics. The possible domestic demand shifters that are included are GDP as the resource constraint, population, and civilian (nonmilitary) public spending. All expenditure variables and income (GDP) are in constant prices (2011 USD). We rewrite equation (1) as:

(2) $\ln M_{t}=\beta \ln p_{t}+\ln A_{(t-1)}$.

The estimated equation (2) explains a high proportion of the variance of the dependent variable, with an $\mathrm{R}^{2}$ of 0.84 (Table 2). The results are fairly consistent when it comes to the coefficients of the external threat variables. Neither Turkish military expenditure (TRmilex) nor the military tension index (airspace violations) seem to exert any statistically significant influence. Yet the findings do seem to strongly suggest that during the period in question, the domestic demand shifters, with the exception of population, are the ones that influence 
Greek military expenditure with an income elasticity of 0.66 and the elasticity of total civilian expenditure of 0.62 . The alliance spill-ins, approximated by U.S. military spending, are also statistically significant. The negative sign of the relevant coefficient can be tentatively interpreted as indicating free-riding behavior on the part of Greece. Overall, on the basis of the results obtained, it would appear that the domestic economy in the case of Greece, emerges as a major factor that influences its military outlays. In other words, the economy is a formidable constraint that supersedes security needs and challenges. $^{10}$

\section{Conclusion}

Over the past two decades or so, Greece underwent significant changes that affected its position in the regional geopolitical setting of the eastern Mediterranean. Coming off a relatively thriving economy in the 1990s and early 2000s, it is now struggling with an acute recession caused by its sovereign debt crisis. In terms of military expenditure, it invariably ranked as one of the countries with a comparatively high military burden, justified in terms of the external security challenges it faced. But, allowing for how the selection of the time period and the methodology employed can bear on the results, the findings reported in this article suggest that the upward and downward trends observed in Greek military spending (Figure 1) are not so much driven by changes in Greek-Turkish relations, that up to the late 1990s oscillated from tension to negotiation and rapprochement, but by Greece's (in)ability to allocate scarce resources to national defense. Although Turkey features prominently on the Greek security canvas, it appears to be the economy that ultimately moves the defense sector paintbrush used to cover security needs and gaps. Hence, in periods of relative economic affluence, increases to the defense budget were possible. The onset of the acute economic crisis in the late 2000s halted this ability. While the sharp reduction in Greek military expenditure observed since then coincided with a period of calm and cordiality in Greek-Turkish relations, as no major incident has marred their bilateral affairs in the last decade and a half, the statistical evidence suggests that it is the state of the economy, rather than the state of Greek-Turkish security affairs, that is largely responsible for Greece's declining military expenditure.

Nevertheless, the underlying strategic differences between the two countries have not been resolved and, hence, it is possible that they can flare up and lead to a renewed period of tension in the future. However, as two analysts point out, on the one hand, investing in the economy is a precondition in order to attain military deterrence and security. Yet, on the other hand, as a country becomes economically stronger and more affluent, confrontation becomes less of a policy option since too much is at stake to risk in a conflict. Hence, they conclude that "the best way to security may be trough economic growth."

Currently, both Greece and Turkey face challenges that require cooperation rather than confrontation. The increasing flow of irregular immigrants and refugees pose substantial difficulties for both countries, and to the EU. These difficulties may form a basis on which mutual coordination can lead to careful steps forward in their bilateral relation. But they can also bring to the surface long-term strategic differences over the delineation of territorial waters. Such differences can be further accentuated by both countries' aspiration to play a key role in the regional energy game that is unfolding. Eventually, this will involve the delineation of exclusive economic zones both between Greece and Turkey but also with Cyprus, Egypt, and Israel. This multiplayer process can prove very thorny, leading to a deterioration in bilateral relations. However, currently both countries are preoccupied with more pressing problems: Greece with the efforts to get its economy back on track, and Turkey with important security challenges on its southeastern border and the potential threats from a de facto Kurdish state emerging from the turmoil in the region. ${ }^{12}$

Notes

1. In many published papers: A comprehensive and critical survey can be found in Brauer (2002, 2003). Arms race context: Recent examples are Şahin and Özsoy (2008); Öcal (2002); Öcal and Yildirim (2009); Michail and Papasyriopoulos (2012). Methodological problems: Brauer (2002, 2003).

2. Historical relations: See, e.g., Dokos and Tsakonas (2003); Sonmezoglu and Ayman (2003). Tension, negotiation, tension: Gunluk-Senesen $(2001,2004)$. Öcalan affair: The leader of the Kurdish guerrilla group PKK which engaged in armed struggle for the creation of a Kurdish independent state. The PKK is considered as a terrorist organization by the USA, NATO, and the EU. Öcalan has been in jail since his arrest. Rapprochement: Due to the catalytic role of the earthquakes, the diplomatic rapprochement was termed "earthquake diplomacy." Long-standing bilateral disputes: (see, e.g., Sonmezoglu and Ayman (2003); Dokos and Tsakonas (2003); Kollias and Paleologou (2011).

3. Greek domestic political and partisan scene: See, e.g., Vasilopoulou, Halikiopoulou, and Exadaktylos (2014); Katsimi and Moutos (2010); Onis (2009, 2012); Kotios, Pavlidis, and Galanos (2011); Onis and Kutlay (2013); Mitsopoulos and Pelagidis (2015).

4. Cordiality and cooperation: Bir and Sherman (2002); Athanasopoulou (2003); Tsakiris (2014). Turkey was the first Muslim country to recognize Israel de jure, signing a commercial agreement with it in 1950. Energy profile: 
Tziampiris (2015); Stergiou (2013, 2015); Good (2014); Tsakiris (2014).

5. Reconfiguration: Stergiou (2015); Eksi (2010); Andoura and d'Oultremont (2013); Dokos (2011); Onis and Yilmaz, 2009; Rumelili (2007).

6. Several factors: Smith $(1989,1995)$; Douch and Solomon (2014). Airspace violations: Pitsoulis and Schwuchow (2014); Kollias and Paleologou (2007); Kollias (2004). Signaling game: Pitsoulis and Schwuchow (2014).

7. Airspace violations: Delving into the legal and other technicalities associated with the practice is beyond our scope here. A summary presentation of such issues can be found in Pitsoulis and Schwuchow (2014), Kollias and Paleologou (2007). Visually-based approach: Pitsoulis and Schwuchow (2014) offer a technically thorough treatment of the time series.

8. Diplomatically embarrassing: Pitsoulis and Schwuchow (2014).

9. Final illustration: Pitsoulis and Schwuchow (2014).

10. The economy supersedes: In Cicero's words: Nervos belli, pecuniam (the nerve of war is money).

11. Two analysts: Dunne and Tian (2013).

12. Unfolding energy game: Tziampiris (2015); Stergiou (2015); Good (2014); Tsakiris (2014); Eksi (2010).

\section{References}

Andoura, S. and C. d'Oultremont. 2013. "The Role of Gas in the External Dimension of the EU Energy Transition." Notre Europe -Jacques Delors Intitute, Policy Paper 79. http://www.delorsinstitute.eu/011-15453-The-role-of-gas -in-the-external-dimension-of-the-EU-energy-transition.h tml.

Athanasopoulou, E. 2003. "Responding to a Challenge: Greece's New Policy Towards Israel." Southeast European and Black Sea Studies. Vol. 3, No. 1, pp. 108-125. http://dx.doi.org/10.1080/713999339

Bir, Ç. and M. Sherman. 2002. "Formula for Stability: Turkey Plus Israel." Middle East Quarterly. Vol. 5, No. 4, pp. 23-32.

Brauer, J. 2002. "Survey and Review of the Defence Economics Literature on Greece and Turkey: What have We Learned?" Defence and Peace Economics. Vol. 13, No. 2, pp. 85-107. http://dx.doi.org/10.1080/10242690210969

Brauer, J. 2003. "Turkey and Greece: A Comprehensive Survey of the Defence Economics literature," pp. 193-241 in C. Kollias and G. Gunluk-Senesen, eds., Greece and Turkey in the 21st Century. The Political Economy Perspective. New York: Nova Science Publishers.

Dokos, T. 2011. "Mediterranean 2020. The Future of the Mediterranean Security and Politics." The German Marshall Fund of the United States. http://www.gmfus.org/publications/mediterranean-2020-f uture-mediterranean-security-and-politics.

Dokos, T. and P. Tsakonas. 2003. "Greek-Turkish Relations in the post-Cold War Era," pp. 9-35 in C. Kollias and G. Gunluk-Senesen, eds., Greece and Turkey in the 21st Century. The Political Economy Perspective. New York: Nova Science Publishers.

Douch, M. and B. Solomon. 2014. "Middle Powers and the Demand for Military Expenditures." Defence and Peace Economics. Vol. 25, No. 6, pp. 605-618. http://dx.doi.org/10.1080/10242694.2013.861652

Dunne, J.P. and N. Tian. 2013. "Military Expenditure and Economic Growth: A Survey." The Economics of Peace and Security Journal. Vol. 8, No. 1, pp. 5-11. http://dx.doi.org/10.15355/epsj.8.1.5

Eksi, M. 2010. "The Role of Energy in Turkish Foreign Policy." The Turkish Yearbook of International Relations. Vol. 41, pp. 62-65.

Good, A. 2014. "East Mediterranean Natural Gas and Israel's Regional Foreign Policy." IMES Capstone Paper Series. The Elliott School of International Affairs. George Washington University. Institute for Middle East Studies, pp. 25-36.

Gunluk-Senesen, G. 2004. "An Analysis of the Action-Reaction Behaviour in the Defence Expenditures of Turkey and Greece." Turkish Studies. Vol. 5, No. 1, pp. 78-98. http://dx.doi.org/10.1080/14683849.2004.9687243

Gunluk-Senesen, G. 2001. "Turkish Defence Expenditures in View of the Ups and Downs in Turkish-Greek Relations: Is there a Reaction?" Hellenic Studies. Vol. 9, No. 2, pp. 73-89.

Katsimi, M. and T. Moutos. 2010. "EMU and the Greek Crisis: The Political Economy Perspective." European Journal of Political Economy. Vol. 26, No. 3, pp. 568-576. http://dx.doi.org/10.1016/j.ejpoleco.2010.08.002

Kollias, C. 2004. "The Greek-Turkish Rapprochement, the Underlying Military Tension and Greek Defence Spending.” Turkish Studies. Vol. 5, No. 1, pp. 99-116. http://dx.doi.org/10.1080/14683849.2004.9687244

Kollias, C., and S.M. Paleologou. 2007. "Military Tension and Defence Spending Dynamics Between Greece and Turkey," pp. 133-149 in W. Elsner, ed., Arms, War and Terrorism in the Global Economy Today: Economic Analysis and Civilian Alternatives. Hamburg: LIT Verlag.

Kollias, C., and S.M. Paleologou. 2011. "The Macroeconomic Effects of Conflict: Three Case Studies," pp. 341-361 in D. Braddon and K. Hartley, eds., Handbook on the Economics of Conflict. Cheltenham, UK: Edward Elgar. http://dx.doi.org/10.4337/9780857930347.00020

Kotios, A., G. Pavlidis, and G. Galanos. 2011. "Greece and the Euro: The Chronicle of an Expected Collapse." Intereconomics. Vol. 46, No. 5, pp. 263-269. http://dx.doi.org/10.1007/s10272-011-0390-7

Michail, M., and N. Papasyriopoulos. 2012. "Investigation of the Greek-Turkish Military Spending Relation." International Advances in Economic Research. Vol. 18, No. 3, pp. 259-270. http://dx.doi.org/10.1007/s11294-012-9362-3 
Mitsopoulos, M., and T. Pelagidis. 2015. "Give Greece a Chance." Intereconomics. Vol. 50, No. 2, pp. 91-97. http://dx.doi.org/10.1007/s10272-015-0530-6

Öcal, N. 2002. "Asymmetric Effects of Military Expenditure Between Turkey and Greece." Defence and Peace Economics. Vol. 13, No. 5, pp. 405-416. http://dx.doi.org/10.1080/10242690213511

Öcal, N., and J. Yildirim. 2009. “Arms Race Between Turkey and Greece: A Threshold Cointegration Analysis." Defence and Peace Economics. Vol. 20, No. 2, pp. 123-129. http://dx.doi.org/10.1080/10242690801962254

Öniş, Z. 2009. "Beyond the 2001 Financial Crisis: The Political Economy of the New Phase of Neo-Liberal Restructuring in Turkey." Review of International Political Economy. Vol. 16, No. 3, pp. 409-432.

http://dx.doi.org/10.1080/09692290802408642

Öniş, Z. 2012. "The Triumph of Conservative Globalism: The Political Economy of the AKP Era." Turkish Studies. Vol. 13, No. 2, pp. 135-152. http://dx.doi.org/10.1080/14683849.2012.685252

Öniş, Z. and M. Kutlay. 2013. "Rising Powers in a Changing Global Order: The Political Economy of Turkey in the Age of BRICS." Third World Quarterly. Vol. 34, No. 8, pp. 1409-1426. http://dx.doi.org/10.1080/01436597.2013.831541

Öniş, Z. and Ş. Yilmaz. 2009. "Between Europeanization and Euro-Asianism: Foreign Policy Activism in Turkey During the AKP Era." Turkish Studies. Vol. 10, No. 1, pp. 7-24. http://dx.doi.org/10.1080/14683840802648562

Pitsoulis, A., and S. Schwuchow. 2014. "Coercion, Credibility, and Mid-Air Interceptions of Military Planes." Peace Economics, Peace Science \& Public Policy. Vol. 20, No. 4, pp. 697-707. http://dx.doi.org/10.1515/peps-2014-0040

Rumelili, B. 2007. "Transforming Conflicts on EU Borders: The Case of Greek-Turkish Relations." Journal of Common Market Studies. Vol. 45, No. 1, pp. 105-126. http://dx.doi.org/10.1111/j.1468-5965.2007.00705.x

Şahin, H., and O. Özsoy. 2008. "Arms Race between Greece and Turkey: A Markov Switching Approach.” Defence and Peace Economics. Vol. 19, No. 3, pp. 209-216. http://dx.doi.org/10.1080/10242690801972154

Smith, R. 1989. "Models of Military Expenditures." Journal of Applied Econometrics. Vol. 4, No. 4, pp. 345-359. http://dx.doi.org/10.1002/jae.3950040404

Smith, R. 1995. "The Demand for Military Expenditure, pp. 69-87, in K. Hartley and T. Sandler, eds., Handbook of Defence Economics. Vol. 1. Amsterdam: North Holland.

Sönmezoğlu, F., and G. Ayman. 2003. "The Roots of Conflict and the Dynamics of Change in Turkish-Greek Relations," pp. 37-48 in C. Kollias and G. Gunluk-Senesen, eds., Greece and Turkey in the 21st Century. The Political Economy Perspective. New York: Nova Science Publishers.

Stergiou, A. 2013. "Geopolitics: Greece, Cyprus and Israel Change the Military Balance in the Mediterranean."
Geopolitical Information Service-GIS. http://www.geopolitical-info.com/en/geopolitics/greece-c yprus-and-israel-change-the-military-balance-in-the-medi terranean.

Stergiou, A. 2015. "Greek-Israeli Defense and Energy Ties: Writing a New Chapter in Bilateral Relations." Israel Journal of Foreign Affairs. Vol. 9, No. 3, pp. 417-428. http://dx.doi.org/10.1080/23739770.2015.1126778

Tsakiris, T. 2014. "Shifting Sands or Burning Bridges? The Evolution of Turkish-Israeli Relations after the Mavi Marmara Incident and the Strategic Energy Calculations of Greece \& Cyprus.” ELIAMEP Policy Paper No. 22. http:/www.eliamep.gr/wp-content/uploads/2014/02/polic y-paper.pdf.

Tziampiris, A. 2015. The Emergence of Israeli-Greek Cooperation. Berlin: Springer International. http://dx.doi.org/10.1007/978-3-319-12604-3

Vasilopoulou, S., D. Halikiopoulou, and Th. Exadaktylos. 2014. "Greece in Crisis: Austerity, Populism and the Politics of Blame." Journal of Common Market Studies. Vol. 52, No. 2, pp. 388-402.

http://dx.doi.org/10.1111/jcms.12093 